\title{
The Need for a Journal of Digital Innova- tion for Humanity - JDIH
}

\author{
Raafat George Saadé \\ Montreal, Canada
}

Aim/Purpose This article presents the results of reviewing journal outlets where research in digital innovation and transformation are published. Our aim is to make the case for a much-needed journal dedicated research and practice in the digital innovation / transformation and human / humanity sphere.

Background Digital innovation has become part of our daily lives whether we are aware of it or not. Over 4 billion people are using blockchain, IoT, cloud computing, mobile technologies, social media and artificial intelligence, yet very little is understood of their effects on humans. Research in this area is relatively scarce and dispersed across diverse types of journals. The few articles published in the area of digital innovation and humanity provide just a hint on the importance of the subject matter. Ultimately, we need to understand what technology is for humans. Is the digitalization phenomenon a utopia or a dystopia? What we really need is a truly human-centered transformation of digital innovation.

Methodology The Publish and Perish literature search desktop application and Google search engine were used to identify journals that have published in the area of digital innovation with a focus on humanity. SCIMAGO was used to understand the subject area clusters of these journals.

Findings There is relatively little research in the digital innovation and humanity arena. Articles are scarce and dispersed over a diversified range of journal subject areas. Only two journals are concentrated on publishing research in the area of digital innovation. No journals were found in humanity and digital innovation.

Impact on Soci- In this article, we stress the need for a journal in digital innovation and humanety ity as an outlet for the work of researchers, practitioners, and educators. The article inaugurates the first paper for the journal. The journal will act as an outlet for researchers, practitioners, and educators and provide a forum for knowledge sharing and collaboration with the ultimate goal of improving human quality of life.

Keywords Digital Innovation \& Transformation, Humanity, Journals 
Volume 1, 2020

JOURNAL OF DIGITAL INNOVATION FOR HUMANITY

Transformation of Digital Innovation for a Better Quality of Life

\section{AREAS OF CONTRIBUtion}

\begin{tabular}{lllll} 
Paper Category & & \\
\hline$\square \quad$ Original Research & $\square$ & Position Paper & $\square$ & Comparative \\
$\square \quad$ Case Study & $\square$ & Technical Briefs & $\square$ & Opinion \\
$\square \quad$ Reviews & $\square$ & Student Paper & $\square$ & Innovation Ideas \\
\hline
\end{tabular}

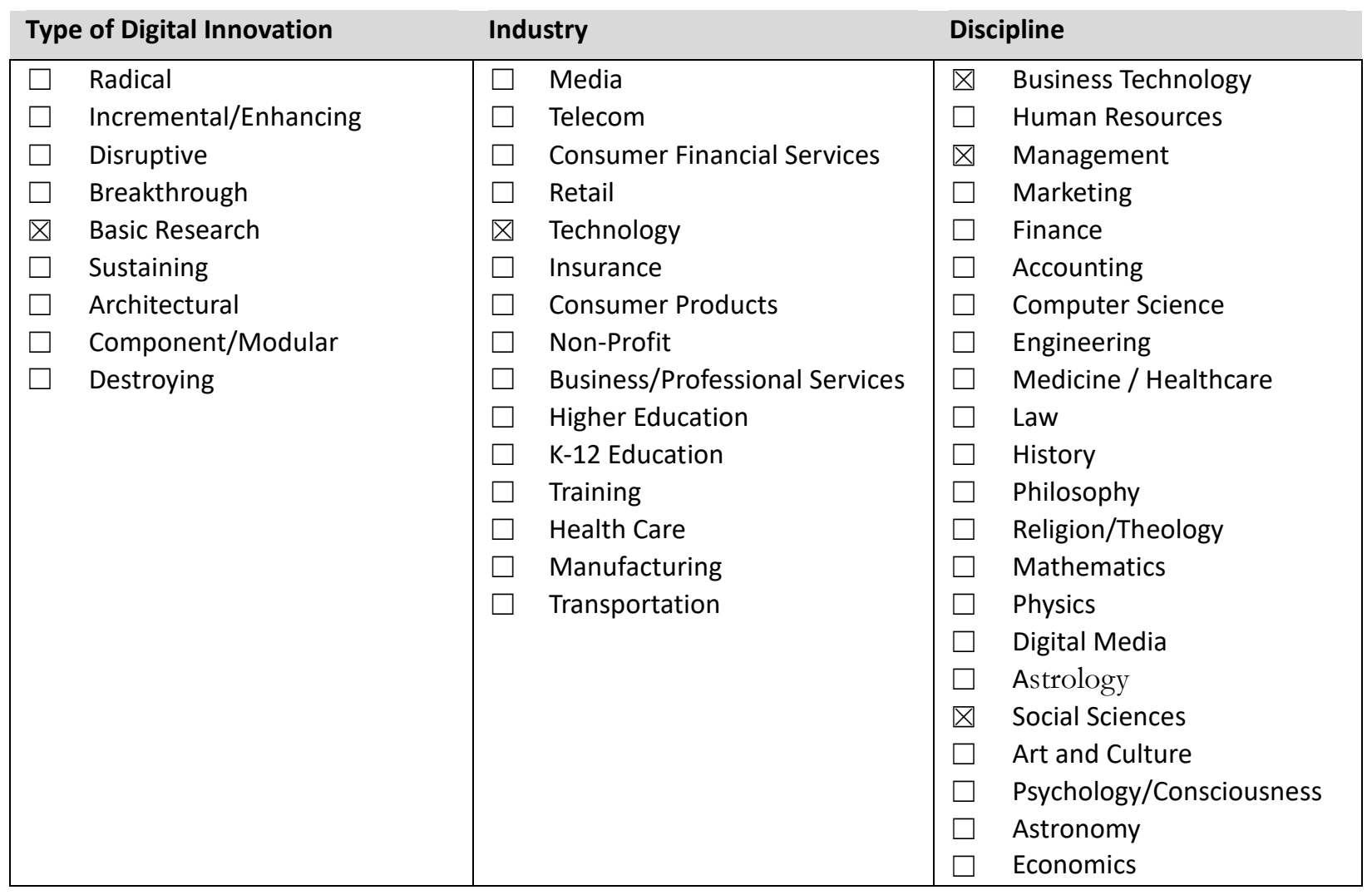

\section{Human Elements Addressed}

\begin{tabular}{|c|c|c|c|c|c|}
\hline$\square$ & Personality Traits & $\square$ & Development & $\square$ & Mental Wellbeing \\
\hline 凶 & Behaviour & $\square$ & Environmental & $\square$ & Consciousness \\
\hline 凶 & Cognition & $凶$ & Social & $\square$ & Physical Wellbeing \\
\hline
\end{tabular}




\section{INTRODUCTION}

\section{Digital Innovation}

Digital trends continue to impact humanity, including organizations, governments and society/communities, in various ways. Although somewhat aware of the technology-induced changes occurring in all aspects of our lives, we know very little about the breadth and depth of this impact. Currently, the major shift towards a digitally-enabled and integrated world is due to technological advances/innovations primarily from artificial intelligence, blockchain, the internet of things, cloud computing, , big data, social media, mobile computing, and 5G telecommunications.

The adoption of these novel digital innovations by individuals, organizations and governments has led to serious changes in various human dimensions such as digital skills, data processing, multitasking, business processing, decision making and policy making (Galán-Díaz, Edwards, \& Nelson, 2015). Inevitably, digital innovations have proven to result in positive outcomes in some cases, while simultaneously creating many challenges at all levels (individual, society, organization, government) and increased the level of uncertainty in the way digital innovations are created and consumed. The decreasing quality of people interactions across and between gender, culture and age groups and digital engagement fatigue are a few examples of the negative transformative effects of digital technologies. Nevertheless, more individuals and organizations continue to adopt new digital innovations because they are made to believe that their businesses and lives will improve with their use.

Digital innovations continue to evolve across research, practice and education. Digital innovations can be of many types: radical, incremental, enhancing, disruptive, breakthrough, sustaining, architectural, modular and destroying. A digital innovation can be created and exist in any industry from retail to education. It is multi-disciplinary, occurring in any field or combination thereof, in business, engineering, computer science, healthcare, arts, science, and humanities. At the same time, digital innovations affect the entire human chain from the individual physical and mental state, family, friends, community, society, culture, organization, government and environment. What is common to all digital innovation dimensions is the human element as it weaves its thread through the fibres of the buman impact chain.

Digital innovations are astonishing in how they have upset and disrupted existing and well-established paradigms, notions, and processes. Most of the rhetoric and discussion has been focused on the business sense only. More importantly and to a much lesser degree, dialogue on how digital innovations have disrupted and changed humans altogether: lifestyle, behavior, and physiology, has not occurred yet. Moreover, as these innovations continue to accelerate at a faster pace, a race between digital technologies and humans is nurtured with little understanding of the ever-increasing relationship gap. If this has not already happened, it is expected that computers will surpass human workers and redefine the paradigm of our existence. It seems that everyone is overtaken with keeping up with computers and no one is preparing for the aftermath. What will humans do when computers take over many, if not all aspects of our lives?

There does not seem to be a consensus on the definition of digital innovation, it is viewed differently depending on whether one sees innovation from a process viewpoint or outcome perspective. Even the concept of innovation alone has many definitions depending on whom you ask. Some of the definitions of innovation include the following: 


\title{
66
}

\begin{abstract}
Innovation is a process that begins with an invention, proceeds with the development of the inventions, and results in the introduction of a new product, process or service to the market place-Acs \& Audretsch, 1988

Innovation is defined as the adoption of an idea or behavior whether a system, policy, program - Damanpour, 1992
\end{abstract}

Innovation behavior can be defined as all individual actions directed at the generation, introduction and application of beneficial novelty at any organization level - De Jong \& Kemp, 2003

Innovation is an idea, practice or object that is perceived as new to an individual or another unit of adoption - Fruhling \& Siau, 2007

Innovation refers to the creation of new product within the firm - Geiger \& Cashen, 2002

Organizational innovation has been consistently defined as the adoption of an idea of behavior that is new to the organization. The innovation can either be a new product, a new service, a new technology, or a new administrative practice - Hage, 1999

A technologically new or significantly enhanced product compared to the firm's previous product which has been commercialized on the market-Palmberg, 2004

Innovations vary in complexity and can range from minor changes to existing products, processes, or services to breakthrough products, and processes or services that introduce firsttime features or exceptional performance-Dibrell et al., 2008

Including the notion of digital in the definition of innovation creates another level of complexity, making it even harder to be specific. Below are some attempts to define digital innovations.

\section{6}

The carrying out of new combinations of digital and physical components to produce novel product - Yoo et al., 2010

The creation of (and consequent change in) market offering, business processes, or models that result from the use of digital technology - Nambisan et al., 2014

A product, processor or business model that is perceived as new, requires some significant changes on the part of adopters, and is embodied in or enabled by IT - Fichman et al., 2014

There are some associations that deal with digital innovation and digital humanities, however, they seem to be limited in their impact on the research arena. Moreover, the education sector has only just started addressing or responding to the need for digital innovation and digital humanities education. Nevertheless, some academic institutions are starting to integrate courses in digital innovation into their existing curricula of management of information systems and computer science. 
Having said that, Franke and Zoubir (2020) hit the nail on the head when they asked the question "How do we define what technology for humans?", in their article entitled,

\begin{tabular}{c}
66 \\
Technology for the People? Humanity as a Compass for the Digital Transformation. \\
Franke \& Zoubit, 2020 \\
\hline
\end{tabular}

Is that not what technology or digital innovations should be about? In their article, they suggest that technology is simply a tool that enables humans to use resources such as time and mobility. Historically, humans were innovating with a wide range of artifacts to help utilize resources effectively and to fulfill their physiological and psychological needs. We can view digital innovation and transformation from a psychological perspective. The goal of psychology is to identify and understand which factors lead to better mental well-being. In a similar fashion, should not digital innovation/transformation enable organizations and humans to identify and understand the factors (organizational and social) that lead to better human states?

There are many scenarios that can be imagined for the state of the future digital human. Some scenarios can be optimistic while others are pessimistic. From an optimistic perspective, one can imagine conditions where digital innovations increase quality of life in general, create an environment where universal basic income is possible and where time is managed effectively. From a pessimistic point of view, some scenarios can include the usual loss of jobs to artificial intelligence, cybersecurity, and digital sovereignty and the dehumanization of the person.

We do not have to wait for the future to see the impact of digital innovations on humans. Today, for example, we have thousands of apps available to use on smart mobile devices. Therefore, one would expect that smartphones loaded with apps might surely raise the standard of living, yet in one study by Twenge et al. (2018); it was shown that in the teenage group, psychological well-being decreased with increased screen time. With increased screen time, in general, every human, faces cognitive challenges in information processing because of limited attention and working memory resources. As we, all experience, every now and then, the unconscious use of media without reflection. All of this is a clear indication of depleting attention resources.

Today, the world is faced with one paradigm - that of "driven by innovation". In this paradigm, the human state is as such: Organizations continue to digitally innovate with whatever is feasible to increase profits while humans are to adapt and avoid direct and indirect outcomes, much of which seem to be negative. 


\section{The Humanity Factor}

The relentless machination of cybernetization since the start of the digital evolution of information and communication technologies in the 21st Century, has reached a point of growing reticulation of the human ecosystem. Invasion by media technologies at all scales, including but not limited to, smart cities, real-time evolving artificial intelligence agents, and the daily-life-colonization via various digital mediums like "social networks" have significantly changed our lives.

Thus, the revealing human-digital-condition becomes the contemporary novel ecosystem that necessitates the rethinking of the humanities and the world around us, in the context of digital capitalism and hyper-digital society. This digital to human participation and engagement, induces us to attempt new complex theories that describe new forms of subjectivity, objectivity and agentivity, forcing us to re-consider the relationship between nature and digital, as much as, between human and non-human.

These fundamental human transformations inspired (or perhaps forced) by the digital machines alter thought at an absolute level and demonstrate the link between the digital civilization and the associated conception of the contemporary human condition in the new digital world. The conception of a "Human" is already well on its way to being thought of as a definable digital-species in a horizon full of limitless possibilities.

Even though digital innovations have brought many benefits to individuals, society, governments and institutions in general, there is a clear indication that in some it has caused adverse effects. In their article, Yamamoto \& Ananou (2015) frame human nature in terms of four dimensions: cognition, social interaction, emotion, and ethics. They argue that although the basic nature of humans seems to remain relatively the same, these four dimensions have been altered by the intermediation of digital technologies between people and their environment.

They advocate that we need to use technology such that digital innovations support and do not disrupt those four dimensions. People's choice and level of interaction with digital innovations need to be such that they are allowed to live in harmony and healthy coexistence with technology (Yamamoto \& Ananou, 2015).

This paper makes the case for the need for an outlet specialized in digital innovation and transformation research and its relationship to the human/humanity paradigm. We began this section by defining and elaborating on digital innovation and then putting it into the human perspective. Naturally, we are tempted to ask whether digital technologies are forming us, or whether we are forming them. In the next section, we explore which journals researchers published their digital innovation studies, followed by identifying and describing the journals that are focused on digital innovation (having the words digital and innovation in their title). Publish or Perish (Harzing, 2007) desktop tool, SCIMAGO and Google search engine were used to obtain the information we were seeking. The results are presented in the section that follows. We then provide a brief summative discussion of our findings and conclude with the need for a journal that focuses on digital innovation and human/humanity. 


\section{REVIEW OF JOURNALS}

\section{'Publish or Perish' Article Search}

In order to identify the different outlets where digital innovation and transportation research work is published, we use Publish or Perish (Harzing, 2007), which is a desktop software program that retrieves and analyzes academic citations using different user-selected data sources. In this study, we selected 'Google Scholar' to obtain the raw citations. The results of the search produce article information namely authors, title, year, publication, publisher as well as a number of metrics such as (most important listed) the Hirsch's h-index which is a metric of an academic's impact, combining quality with quantity.

The Publish or Perish tool is designed "...to empower individual academics to present their case for research impact to its best advantage. We would be concerned if it would be used for academic staff evaluation purposes in a mechanistic way."

Using Publish or Perish tool, we performed a few searches to identify the outlets for published research articles. We report some of the basic findings before we list the publishers and journals found. Research in digital transformation seemed to be more popular than in digital innovation. Research output in digital innovation and transformation entailed a total of 635 articles, $37 \%$ of which are in business, and $22 \%$ in education, totalling close to $60 \%$. If we factor 'strategy' as part of business, the number of publications increases to about $66 \%$.

Considering human/society/humanity areas of study to digital innovation/transformation, we found that the areas of human/humanity and society encompassed only approximately $3 \%$ of digital innovation and $8 \%$ in digital transformation. It is clear that research in the areas of human/humanity and society is lacking significantly.

Excluding conferences and books, we list in tables 1 and 2 the journals where the research has been published. Table 1 includes the 33 journals that published articles related to digital innovation/transformation. With an additional keyword of 'human', 10 journals were identified. Interestingly, there are no common journals between the two lists.

Table 1. Sample of journals and publisher outlets for digital innovation/transformation research.

\begin{tabular}{lll}
\hline \multicolumn{2}{l}{ Journal } & Publisher \\
\hline 1. & Business Horizons & Elsevier \\
2. & Business, Society and Politics & Emerald \\
3. & Business Information Systems and Technology 4.0 & Springer \\
4. & Business Process Management Journal & Emerald \\
5. & Business \& Information Systems Engineering & Springer \\
6. & Cyberspace & Springer \\
7. & Digital Business Models & Springer \\
8. & Economic Research & Taylor \& Francis \\
9. & European Journal of Management and Marketing Studies & Taylor \& Francis \\
10. & Foresight & Emerald \\
11. & Foundations of Management & De Gruyter \\
12. & Information Systems, Management, Organization & Springer \\
13. & International Journal of mechatronics and Manufacturing Systems & Elsevier \\
14. & Information \& Management & Elsevier \\
15. & IEEE Transactions on Engineering Systems & IEEE Explore \\
16. & International Journal of Technology, Policy, and Management & Inderscience
\end{tabular}




\begin{tabular}{ll} 
17. Journal of Business Strategy & Emerald \\
18. Journal of Systems and Information Technology & Emerald \\
19. Journal of Intelligent Manufacturing & Springer \\
20. Journal of Business Strategy & Emerald \\
21. Journal of Business Research & Springer \\
22. Journal of Brand Strategy & Ingenta \\
23. Life-Cycle Management of Machines and Mechanisms & Springer \\
24. New Trends in Business Information Systems and .... & Springer \\
25. Organizing for the Digital World & Springer \\
26. Strategy \& Leadership & Emerald \\
27. Strategies for e-Business & Springer \\
28. Shaping the Digital Enterprise & Springer \\
29. Technological Forecasting and Social Change & Elsevier \\
30. Technovation & Elsevier \\
31. Transportation Research & Elsevier \\
32. The TQM Journal & Emerald \\
33. Technology and Creativity & Springer \\
\hline
\end{tabular}

Table 2. Journals and publisher outlets for digital innovation/transformation research as they relate to human/humanity.

\begin{tabular}{lll}
\hline Journal & Publisher \\
\hline 1. & Convergence: The International Journal of Research into New Media & Sage \\
& Technologies & \\
2. & The Journal of Strategic Information Systems & Elsevier \\
3. & Innovation & Emerald \\
4. & International Journal of Human Rights and Constitutional Studies & Inderscience \\
5. & International Journal of English Literature and Social Sciences & IJEL \\
6. & International Journal of Technology Management & Inderscience \\
7. & Journal of Management Information and Decision Sciences & Allied Business Academies \\
8. & Journal of Responsible Technology & Elsevier \\
9. SAGE Open & Sage \\
10. & Strategic HR Review & Emerald \\
\hline
\end{tabular}

We had noticed in tables 1 and 2 that most journals had only one article published in them with the subject matter of digital innovation and transformation. It is clear that the body of research in this area of study is dispersed. This lack of conversion represented by the diversity of journals is indicative of the weakness in the area to define and agree on a common understanding of the issues to be studied. It tells us that despite the hype of the digital world, we have yet to grasp what that means for humanity (including businesses and governments, and not only individuals and societies). 


\section{'SCIMAGO’ Journals Search}

Figure 1 presents the output of the 'shape of science' visualization tool obtained from SCIMAGO for the subject category 'Human-Computer Interaction'. This visualization tool does not provide a keyword search and gives only preset subject categories to select from. There is not one category that includes the word digital. We selected the closest possible to the present subject of interest for information purposes and possible insights. Figure 1, which depicts the journals listed in SCIMAGO, represents a bubble cluster and shows that most journals are closer to the engineering field. There are a few journals closer to the humanities and social sciences such as computers in human behavior, cyberpsychology, behavior and social networking, behavioral science and policy and games and culture. These journals seem to be suitable and more aligned for publishing research in the areas of digital innovation and transformation, especially with a human focus.

For reference, information and insight purposes, we also provide the list of journals produced from the same source within the same category, in table 3, however, those that are open source only. The table provides, for each journal, the country it belongs to, the h-index, the impact factor and other interesting citation metrics. It is clear from the table that most journals are closer to the engineering and computer science fields. One journal 'Human IT' has the human component in its title. There are other high-impact journals, but they are not open source:

- Computers in human behavior

- International journal of human computer studies

- ACM transactions on computer-human interaction

- Human-computer interaction, and

- International journal of human-computer interaction

In order to get a broader picture of the extent of the different journals, we decided to select another complementary (relative to our subject of interest herein) subject category, namely 'management of IT and innovation'. Similar to figure 1 and table 3, we produced figure 2 and table 4 . It is evident from the bubble cluster that when the subject of innovation is under consideration, most journal tend to cluster towards the social sciences and away from engineering and the humanities. As such, table 4 shows that most of the journals are business and applied technology related. Still, no journal seems to have some focus on digital innovation and transformation.

Based on these results, it would be safe to assume that anyone who wants to publish in the area of digital innovation and transformation will have challenges finding the appropriate outlet. Moreover, even if a journal of interest is identified, a major rework of their research is needed to align the language, positioning and the state of thinking to the journal's audience, reviewers and board of editors. 


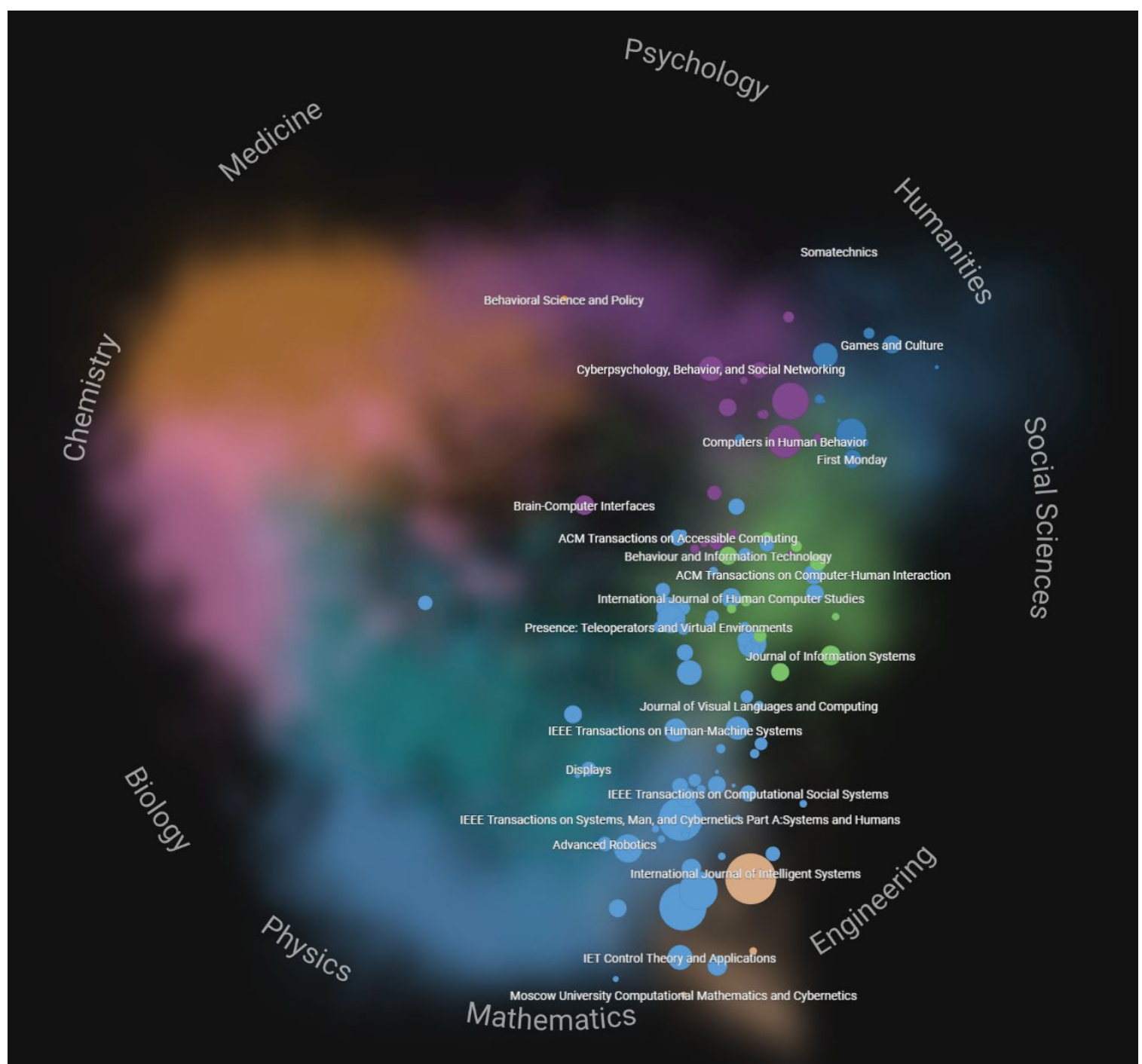

Figure 1. Shape of Science visualization tool from scimagojr.com - Subject: Human-Computer Interaction: Total Journals: 110; Open Access: 24; DI-Relevant: 8. 
Table 3. List of journals from scimagojr.com - Subject: Human-Computer Interaction.

\begin{tabular}{|c|c|c|c|c|c|c|c|c|c|c|c|c|}
\hline & Title & Type & $\stackrel{\downarrow}{\mathrm{SJR}}$ & $\begin{array}{r}H \\
\text { index }\end{array}$ & $\begin{array}{c}\text { Total } \\
\text { Docs. } \\
(2019)\end{array}$ & $\begin{array}{r}\text { Total } \\
\text { Docs. } \\
\text { (3years) }\end{array}$ & $\begin{array}{r}\text { Total } \\
\text { Refs. } \\
(2019)\end{array}$ & $\begin{array}{r}\begin{array}{r}\text { Total } \\
\text { Cites } \\
\text { (3years) }\end{array}\end{array}$ & $\begin{array}{r}\text { Citable } \\
\text { Docs. } \\
\text { (3years) }\end{array}$ & $\begin{array}{r}\text { Cites / } \\
\text { Doc. } \\
\text { (2years) }\end{array}$ & $\begin{array}{r}\text { Ref./ } \\
\text { Doc. } \\
(2019)\end{array}$ & \\
\hline 1 & IEEE Robotics and Automation Letters $\widehat{ఠ}$ & journal & $\begin{array}{r}1.555 \\
\text { Q1 }\end{array}$ & 34 & 536 & 1040 & 14928 & 5196 & 1033 & 4.88 & 27.85 & 塏 \\
\hline 2 & $\begin{array}{l}\text { Journal of Computational Design and } \\
\text { Engineering } \precsim\end{array}$ & journal & $\begin{array}{c}0.739 \\
02\end{array}$ & 17 & 60 & 106 & 2598 & 497 & 102 & 4.12 & 43.30 & $\equiv$ \\
\hline 3 & First Monday $\precsim$ & journal & $\begin{array}{c}0.700 \\
02\end{array}$ & 65 & 25 & 288 & 1365 & 499 & 287 & 1.33 & 54.60 & 琵 \\
\hline 4 & Visual Informatics $\widehat{\varnothing}$ & journal & $\frac{0.673}{0.2}$ & 6 & 18 & 38 & 765 & 120 & 36 & 3.33 & 42.50 & $\equiv$ \\
\hline 5 & Informatics $\precsim$ & journal & $\begin{array}{c}0.395 \\
Q 3\end{array}$ & 7 & 52 & 45 & 2415 & 136 & 44 & 3.09 & 46.44 & + \\
\hline 6 & computers $\precsim$ & journal & $\begin{array}{r}0.361 \\
03\end{array}$ & 14 & 90 & 130 & 3717 & 294 & 125 & 2.32 & 41.30 & + \\
\hline 7 & Paladyn $ఠ$ & journal & $\begin{array}{c}0.332 \\
Q 3\end{array}$ & 5 & 34 & 38 & 1629 & 58 & 38 & 1.56 & 47.91 & $=$ \\
\hline 8 & $\begin{array}{l}\text { Australasian Journal of Information Systems } \\
\text { ¿ }\end{array}$ & journal & 0.296 & 15 & 4 & 95 & 364 & 106 & 86 & 1.15 & 91.00 & 6 웅 \\
\hline 9 & Advances in Human-Computer Interaction $\widehat{ఠ}$ & journal & 0.288 & 19 & 17 & 43 & 562 & 60 & 41 & 1.35 & 33.06 & $=$ \\
\hline 10 & 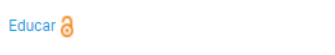 & journal & $\begin{array}{r}0.283 \\
0.3\end{array}$ & 2 & 29 & 26 & 1127 & 11 & 24 & 0.46 & 38.86 & 드. \\
\hline 11 & $\begin{array}{l}\text { International Journal of Computer Games } \\
\text { Technology } \gtrsim\end{array}$ & journal & $\begin{array}{r}0.251 \\
03\end{array}$ & 18 & 7 & 32 & 304 & 42 & 32 & 1.38 & 43.43 & $\equiv$ \\
\hline 12 & South African Computer Journal $\precsim$ & journal & $\begin{array}{c}0.242 \\
0.3\end{array}$ & 4 & 17 & 51 & 575 & 70 & 40 & 1.79 & 33.82 & $\approx$ \\
\hline 13 & $\begin{array}{l}\text { International Journal of Intelligent Systems } \\
\text { and Applications (discontinued) } \gtrsim\end{array}$ & journal & 0.241 & 14 & 0 & 293 & 0 & 396 & 293 & 1.50 & 0.00 & D \\
\hline 14 & Human Technology $ఠ$ & journal & $\begin{array}{c}0.232 \\
03\end{array}$ & 5 & 12 & 40 & 620 & 53 & 34 & 0.71 & 51.67 & \pm \\
\hline 15 & Interaction Design and Architecture(s) $\prec$ & journal & $\begin{array}{r}0.204 \\
03\end{array}$ & 10 & 6 & 109 & 144 & 79 & 95 & 0.91 & 24.00 & 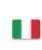 \\
\hline 16 & Computational Social Networks $\prec$ & journal & $\begin{array}{r}0.203 \\
Q 4\end{array}$ & 10 & 14 & 35 & 689 & 33 & 35 & 0.96 & 49.21 & 㪙器 \\
\hline 17 & Journal of Interactive Online Learning $\widehat{\prec}$ & journal & $\begin{array}{r}0.180 \\
Q 4\end{array}$ & 32 & 0 & 18 & 0 & 10 & 18 & 0.42 & 0.00 & 틀 \\
\hline 18 & Webology $ఠ$ & journal & $\begin{array}{r}0.178 \\
Q 4\end{array}$ & 15 & 28 & 41 & 927 & 39 & 39 & 1.15 & 33.11 & $\mp$ \\
\hline 19 & $\begin{array}{l}\text { International Journal of Advances in Intelligent } \\
\text { Informatics } \partial\end{array}$ & journal & $\begin{array}{l}0.172 \\
Q 4\end{array}$ & 7 & 26 & 60 & 910 & 59 & 57 & 1.02 & 35.00 & $=$ \\
\hline 20 & Human IT $\widehat{\partial}$ & journal & $\begin{array}{r}0.159 \\
Q 4\end{array}$ & 8 & 4 & 16 & 238 & 6 & 15 & 0.00 & 59.50 & E \\
\hline 21 & $\begin{array}{l}\text { International Journal of Automation and Smart } \\
\text { Technology } \precsim\end{array}$ & journal & $\begin{array}{l}0.135 \\
Q 4\end{array}$ & 8 & 16 & 74 & 354 & 24 & 73 & 0.38 & 22.13 & $\mathbf{a}$ \\
\hline 22 & $\begin{array}{l}\text { International Journal of Computing and Digital } \\
\text { Systems } \partial\end{array}$ & journal & $\begin{array}{r}0.108 \\
Q 4\end{array}$ & 3 & 65 & 40 & 1998 & 13 & 40 & 0.33 & 30.74 & O \\
\hline 23 & Body, Space and Technology $\precsim$ & journal & $\begin{array}{r}0.107 \\
Q 4\end{array}$ & 1 & 14 & 8 & 433 & 3 & 7 & 0.43 & 30.93 & 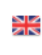 \\
\hline 24 & CrossTalk ఠ & journal & $\begin{array}{c}0.105 \\
\text { Q4 }\end{array}$ & 17 & 0 & 89 & 0 & 9 & 74 & 0.11 & 0.00 & 를 \\
\hline
\end{tabular}




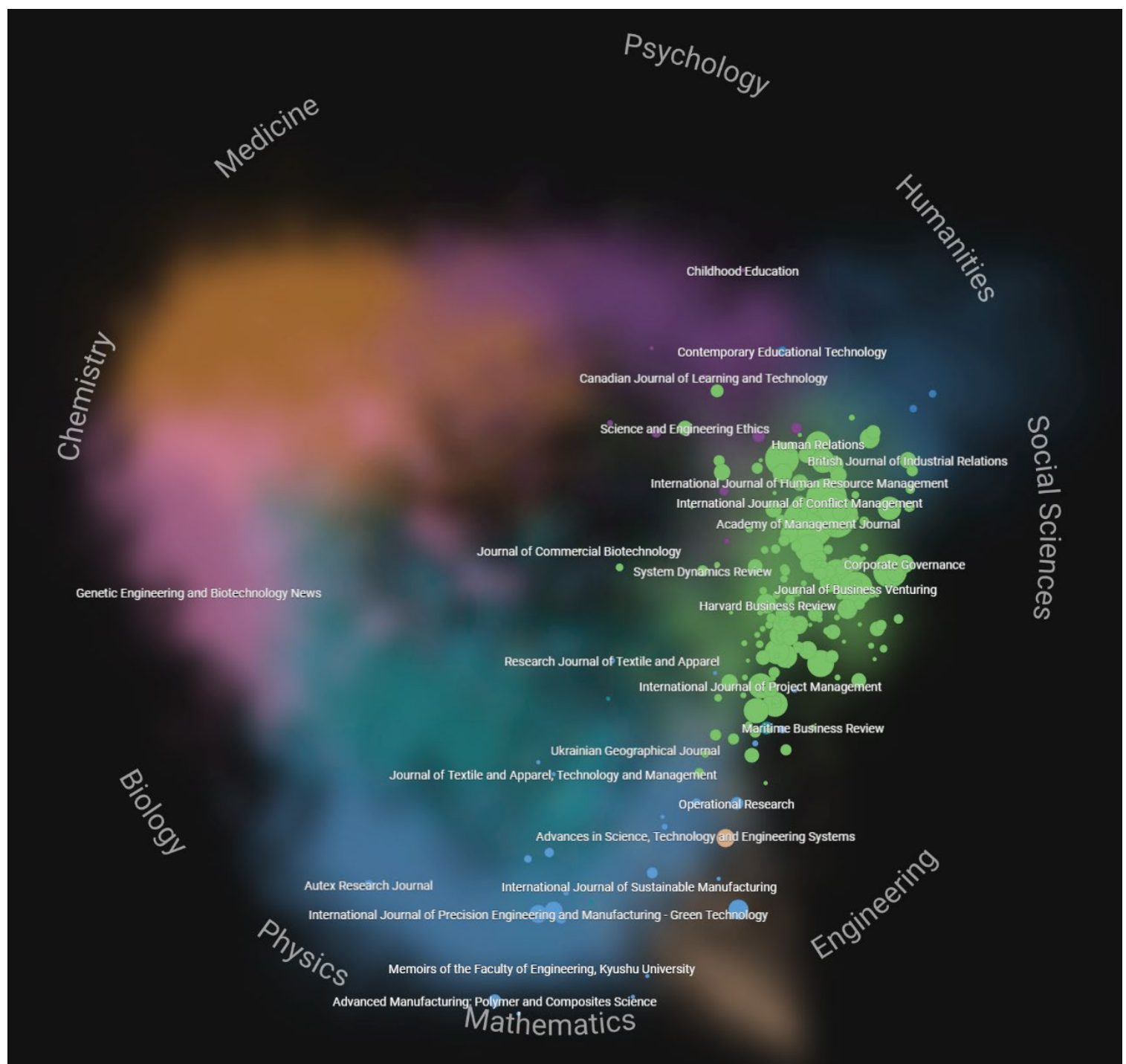

Figure 2. Shape of Science visualization tool from scimagojr.com - Subject: Management of IT \& Innovation: Total Journals: 241; Open Access: 38; DI-Relevant: 2. 
Table 4. List of journals from scimagojr.com - Subject: Management of Technology \& Innovation.

\begin{tabular}{|c|c|c|c|c|c|c|c|c|c|c|c|c|}
\hline & Title & Type & $\stackrel{\downarrow}{\mathrm{SJR}}$ & $\begin{array}{r}\mathrm{H} \\
\text { index }\end{array}$ & $\begin{array}{l}\text { Total } \\
\text { Docs. } \\
(2019)\end{array}$ & $\begin{array}{r}\text { Total } \\
\text { Docs. } \\
\text { (3years) }\end{array}$ & $\begin{array}{l}\text { Total } \\
\text { Refs. } \\
(2019)\end{array}$ & $\begin{array}{r}\text { Total } \\
\text { Cites } \\
\text { (3years) }\end{array}$ & $\begin{array}{l}\text { Citable } \\
\text { Docs. } \\
\text { (3years) }\end{array}$ & $\begin{array}{r}\text { Cites / } \\
\text { Doc. } \\
\text { (2years) }\end{array}$ & $\begin{array}{l}\text { Ref./ } \\
\text { Doc. } \\
(2019)\end{array}$ & \\
\hline 1 & Entrepreneurship and Sustainability Issues $\widehat{\partial}$ & journal & $\begin{array}{r}1.171 \\
\mathrm{Q1}\end{array}$ & 18 & 194 & 168 & 7696 & 964 & 168 & 5.74 & 39.67 & 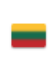 \\
\hline 2 & Financial Innovation $\widehat{\prec}$ & journal & $\begin{array}{r}0.847 \\
02\end{array}$ & 13 & 45 & 96 & 2135 & 477 & 83 & 2.98 & 47.44 & 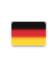 \\
\hline 3 & $\begin{array}{l}\text { Research and Practice in Technology } \\
\text { Enhanced Learning } \partial\end{array}$ & journal & 0.691 & 11 & 26 & 67 & 1200 & 194 & 65 & 2.78 & 46.15 & $=$ \\
\hline 4 & $\begin{array}{l}\text { Advanced Manufacturing: Polymer and } \\
\text { Composites Science } \widehat{ }\end{array}$ & journal & $\begin{array}{r}0.642 \\
02\end{array}$ & 9 & 20 & 33 & 756 & 85 & 32 & 2.17 & 37.80 & 背发 \\
\hline 5 & Interfaces $\widehat{\sigma}$ & journal & $\frac{0.609}{02}$ & 62 & 33 & 124 & 714 & 117 & 116 & 0.92 & 21.64 & 琵 \\
\hline 6 & Asian Journal of Shipping and Logistics $\widehat{\partial}$ & journal & $\begin{array}{c}0.544 \\
02\end{array}$ & 16 & 34 & 102 & 1369 & 244 & 100 & 2.21 & 40.26 & $=$ \\
\hline 7 & Autex Research Journal $\widehat{\partial}$ & journal & $\begin{array}{r}0.452 \\
02\end{array}$ & 30 & 87 & 134 & 1468 & 168 & 119 & 1.41 & 16.87 & $=$ \\
\hline 8 & Knowledge Management and E-Learning $\widehat{\partial}$ & journal & $\begin{array}{r}0.414 \\
02\end{array}$ & 19 & 27 & 100 & 1697 & 153 & 100 & 1.67 & 62.85 & \\
\hline 9 & She Ji $\partial$ & journal & $\begin{array}{c}0.414 \\
02\end{array}$ & 8 & 40 & 94 & 956 & 94 & 53 & 1.84 & 23.90 & $=$ \\
\hline 10 & International Journal of Technology $\widehat{\partial}$ & journal & $\begin{array}{c}0.401 \\
0.22\end{array}$ & 12 & 168 & 501 & 3819 & 589 & 496 & 1.14 & 22.73 & $=$ \\
\hline 11 & $\begin{array}{l}\text { Management and Production Engineering } \\
\text { Review } \partial\end{array}$ & journal & 0.358 & 12 & 47 & 125 & 1731 & 232 & 125 & 1.54 & 36.83 & 0 \\
\hline 12 & $\begin{array}{l}\text { EasternEuropean Journal of Enterprise } \\
\text { Technologies } \partial\end{array}$ & journal & 0.325 & 21 & 466 & 1618 & 11247 & 1663 & 1618 & 1.09 & 24.14 & $=$ \\
\hline 13 & European Journal of Futures Research $\widehat{\partial}$ & journal & $\frac{0.298}{03}$ & 4 & 7 & 41 & 534 & 48 & 41 & 1.17 & 76.29 & 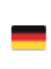 \\
\hline 14 & Journal of Innovation and Entrepreneurship $\widehat{\prec}$ & journal & $\frac{0.289}{0.3}$ & 10 & 6 & 35 & 293 & 71 & 33 & 2.15 & 48.83 & 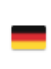 \\
\hline 15 & Intangible Capital $\partial$ & journal & $\frac{0.265}{Q 3}$ & 13 & 14 & 123 & 662 & 132 & 122 & 0.96 & 47.29 & 도 \\
\hline 16 & $\begin{array}{l}\text { Electronic Journal of Knowledge Management } \\
\curvearrowright\end{array}$ & journal & 0.258 & 3 & 12 & 13 & 752 & 15 & 12 & 1.25 & 62.67 & 舆 \\
\hline 17 & Intellectual Economics Ә & journal & $\begin{array}{c}0.236 \\
0.03\end{array}$ & 4 & 7 & 4 & 182 & 22 & 4 & 5.50 & 26.00 & $\square$ \\
\hline
\end{tabular}


Table 4 continued

\begin{tabular}{|c|c|c|c|c|c|c|c|c|c|c|c|c|}
\hline & Title & Type & $\stackrel{\downarrow}{\downarrow}$ & $\begin{array}{r}H \\
\text { index }\end{array}$ & $\begin{array}{r}\text { Total } \\
\text { Docs. } \\
(2019)\end{array}$ & $\begin{array}{r}\text { Total } \\
\text { Docs. } \\
\text { (3years) }\end{array}$ & $\begin{array}{l}\text { Total } \\
\text { Refs. } \\
(2019)\end{array}$ & $\begin{array}{r}\begin{array}{r}\text { Total } \\
\text { Cites } \\
\text { (3years) }\end{array} \\
\end{array}$ & $\begin{array}{c}\text { Citable } \\
\text { Docs. } \\
\text { (3years) }\end{array}$ & $\begin{array}{r}\text { Cites/ } \\
\text { Doc. } \\
\text { (2years) }\end{array}$ & $\begin{array}{r}\text { Ref./ } \\
\text { Doc. } \\
(2019)\end{array}$ & \\
\hline 18 & $\begin{array}{l}\text { RAE Revista de Administracao de Empresas } \\
\varnothing\end{array}$ & journal & $\begin{array}{c}0.218 \\
03\end{array}$ & 13 & 35 & 148 & 1500 & 110 & 136 & 0.61 & 42.86 & $\theta$ \\
\hline 19 & Banks and Bank Systems $\precsim$ & journal & $\begin{array}{l}0.216 \\
03\end{array}$ & 14 & 71 & 191 & 2448 & 112 & 191 & 0.67 & 34.48 & - \\
\hline 20 & $\begin{array}{l}\text { Journal of Technology Management and } \\
\text { Innovation } \precsim\end{array}$ & journal & $\begin{array}{c}0.212 \\
03\end{array}$ & 25 & 41 & 136 & 1882 & 97 & 134 & 0.57 & 45.90 & ㄴ. \\
\hline 21 & Central European Business Review ఠ & journal & $\begin{array}{r}0.209 \\
03\end{array}$ & 3 & 21 & 35 & 854 & 24 & 35 & 0.69 & 40.67 & 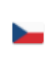 \\
\hline 22 & $\begin{array}{l}\text { Engineering Management in Production and } \\
\text { Services } \partial \text { - }\end{array}$ & journal & 0.203 & 7 & 37 & 93 & 2072 & 100 & 93 & 1.09 & 56.00 & $=$ \\
\hline 23 & $\begin{array}{l}\text { Management Systems in Production } \\
\text { Engineering } \partial\end{array}$ & journal & $\begin{array}{l}0.197 \\
Q 83\end{array}$ & 3 & 39 & 40 & 770 & 26 & 40 & 0.65 & 19.74 & - \\
\hline 24 & Quality Innovation Prosperity $\partial$ & journal & $\begin{array}{r}0.197 \\
Q 3\end{array}$ & 10 & 23 & 73 & 841 & 59 & 72 & 0.85 & 36.57 & $=$ \\
\hline 25 & $\begin{array}{l}\text { Canadian Journal of Learning and Technology } \\
\curvearrowright\end{array}$ & journal & 0.194 & 2 & 9 & 15 & 442 & 10 & 15 & 0.67 & 49.11 & $|+|$ \\
\hline 26 & Business Systems Research $\precsim$ & journal & 0.177 & 4 & 26 & 44 & 1010 & 40 & 43 & 0.93 & 38.85 & $=$ \\
\hline 27 & $\begin{array}{l}\text { Journal of Advanced Manufacturing } \\
\text { Technology } \gtrsim\end{array}$ & journal & 0.173 & 4 & 57 & 172 & 1160 & 60 & 172 & 0.35 & 20.35 & a \\
\hline 28 & TEM Journal $ఠ$ & journal & 0.167 & 5 & 205 & 239 & 3945 & 171 & 239 & 0.72 & 19.24 & a \\
\hline 29 & Informacijos Mokslai ‡ & journal & 0.140 & 1 & 10 & 43 & 485 & 7 & 41 & 0.17 & 48.50 & - \\
\hline 30 & Monthly Labor Review əे & journal & $\begin{array}{l}0.127 \\
Q 4\end{array}$ & 52 & 0 & 178 & 0 & 39 & 107 & 0.52 & 0.00 & 툴 \\
\hline 31 & Tuning Journal for Higher Education $\precsim$ & journal & $\stackrel{0.123}{Q 4}$ & 1 & 7 & 12 & 321 & 3 & 10 & 0.30 & 45.86 & $=$ \\
\hline 32 & Brazilian Business Review $\precsim$ & journal & 0.115 & 2 & 32 & 40 & 1618 & 11 & 36 & 0.31 & 50.56 & 0 \\
\hline 33 & $\begin{array}{l}\text { Journal of Information Technology } \\
\text { Management } \precsim\end{array}$ & journal & $\begin{array}{l}0.110 \\
Q 4\end{array}$ & 2 & 0 & 69 & 0 & 8 & 69 & 0.12 & 0.00 & $=$ \\
\hline 34 & $\begin{array}{l}\text { International Journal of Computing and Digital } \\
\text { Systems } \partial\end{array}$ & journal & $\begin{array}{l}0.108 \\
Q 4\end{array}$ & 3 & 65 & 40 & 1998 & 13 & 40 & 0.33 & 30.74 & = \\
\hline 35 & $\begin{array}{l}\text { International Journal of Recent Technology } \\
\text { and Engineering (discontinued) } \widehat{\partial}\end{array}$ & journal & 0.107 & 17 & 8314 & 196 & 158011 & 31 & 196 & 0.16 & 19.01 & $=$ \\
\hline 36 & $\begin{array}{l}\text { International Journal of eBusiness and } \\
\text { eGovernment Studies } \precsim\end{array}$ & journal & $\begin{array}{c}0.105 \\
Q 4\end{array}$ & 1 & 13 & 16 & 404 & 2 & 16 & 0.13 & 31.08 & c. \\
\hline 37 & Sociologia y Tecnociencia $\precsim$ & journal & $\begin{array}{l}0.102 \\
Q 4\end{array}$ & 0 & 13 & 13 & 478 & 0 & 13 & 0.00 & 36.77 & $=$ \\
\hline 38 & $\begin{array}{l}\text { World Journal on Educational Technology: } \\
\text { Current Issues } 2\end{array}$ & journal & & 2 & 14 & 0 & 380 & 0 & 0 & 0.00 & 27.14 & $\approx$ \\
\hline
\end{tabular}


Using the same source SCIMAGO, and the search tool provided, we decided to search for journals that have the word 'digital' in their title, and found none. We then used the word 'innovation' and the search produced the list given in Table five below.

Table 5. List of journals from scimagojr.com - Search: Innovation.

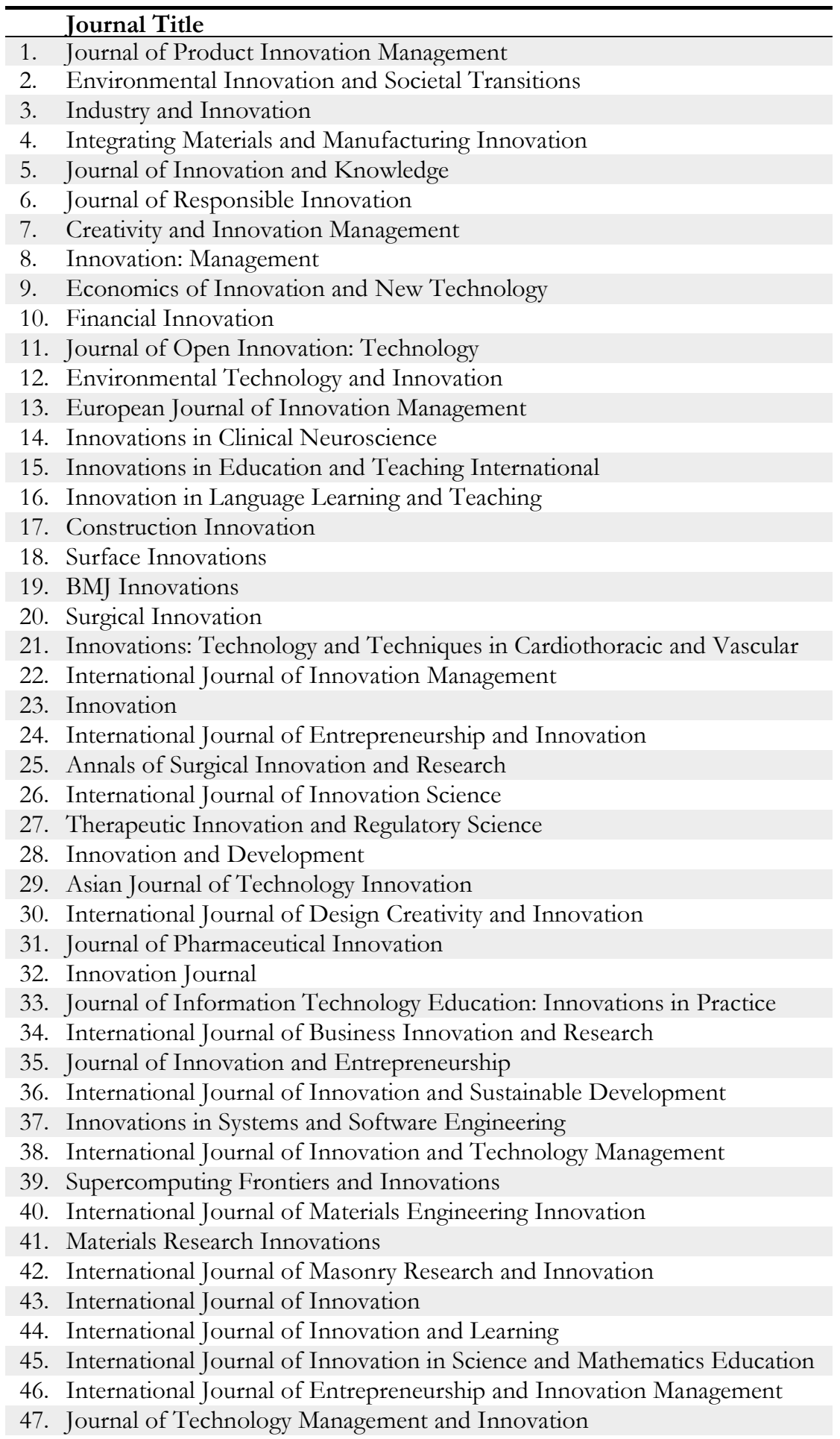


48. International Journal of Engineering and Technology Innovation

49. Recent Innovations in Chemical Engineering

50. Quality Innovation Prosperity

51. International Journal of Foresight and Innovation Policy

52. Investment Management and Financial Innovations

53. Innovations

54. International Journal of Work Innovation

55. Asia-Pacific Journal of Innovation in Hospitality and Tourism

56. International Journal of Software Innovation

57. International Journal of Mobile Network Design and Innovation

58. International Journal of Postharvest Technology and Innovation

59. International Journal of E-Entrepreneurship and Innovation

60. International Journal of Systematic Innovation

61. Innovations in Incidence Geometry

62. Science and Innovation

Of the 62 journals listed in the previous table, only six can be associated with digital innovation and identify with technology innovation, with or without management and software innovation.

\section{Manual Google Search}

Having exhausted all the possibilities to look for journals central to the digital innovation and transformation arenas with human/humanity perspective, we embarked on a manual search using google search engine. In that process, we identified five journals that meet our criteria (we list and elaborate on them - not in any specific order):

1. Journal of innovation in digital ecosystem

discontinued in 2016 and does not have any description on their website)

2. International Journal of Digital Innovation in the Build Environment (IJDIBE)

This journal is focused on the application of digital innovation in new and existing buildings and infrastructure such as new techniques and technologies for the optimization of performance, sustainability, and durability. It addresses research issues ranging from digital design, construction and operations to smart and sustainable buildings, infrastructure, and cities, including building, infrastructure, and city level information modeling, resilient design, machine learning, and digital twins, covering all spatial contexts related to the urban and digital built environment. The journal covers a wide range of topics within Building Sciences and Urban Built Environment perspectives, and we list only some of these topics relevant to the interest of this study:

- Digital Built Environment Futures

- Digital City Modeling

- Digital City Planning \& Management

- Digital Data Capture \& Manipulation

- Digital Design, Construction, Operations, \& Decommissioning

- Digital Engineering \& Digital Twins

- Digital Facilities Management

- Digital Urban Infrastructures 
3. International Journal of Innovation and Technology Management (IJITM) IJITM emphasized the promotion, discussion, reporting, sharing and exchange of ideas in research in the area of technological innovation. This journal however, does not mention the digital arena and is primarily focused on innovation management. We include it here simply for the purpose of innovation in technology management theory and practice, which is critical and very close to digital innovation.

IJITM encourages novel theoretical and practical research that reports on recent trends. The journal focuses on managerial issues and challenges.

4. International Journal of Innovation in the Digital Economy (IJIDE)

IJIDE focuses on new theoretical and practical approaches about the digital economy in general. Its purpose is to increasing awareness on the different issues related to the digital economy. The journal is interdisciplinary and encourages articles to be informative and educative, linking theory with practice. Some of the topics (that are more relevant to our present subject of interest) covered include:

- Ecommerce technologies in modern organizations

- Decision making methods in digital economy

- Innovation based models and management

- Educational technology and innovation

- Impacts of the new resources on individual's life

- Regional economic development strategy

- Roles of information, technology, and innovation in economic policies

- Shape of digital divide

- Strategies and implementations in innovation-based economies

5. Digital Business

Digital Business is an Open Access journal, which publishes research work related to the digitalization of business. Digitalization in the business sense includes areas such as digital technologies impact on business models and future work. Some of the topics covered in the journal that are of interest to the present study, are:

- Digital platforms, ecosystems, transformation, technology and innovation (and social impact)

- Digital strategy and leadership

- Data-centric business models and data monetization

- Big data-driven business models

- Blockchain driven business models

- Social network-driven business models (crowdsourcing, crowdfunding)

- Digital intelligent business models

- IoT driven business models

- Business model innovation, ontology, applications, valuation, change and dynamics

- Digital business model design, development and performance

- Mobile business models

- Impact of Industry 4.0 Technologies on business and ecosystem (which include cyberphysical systems (CPS), Internet of Things (IoT), Industrial Internet of Things (IIOT), 
Cloud Computing, Cognitive Computing, Machine-learning (ML), and Artificial Intelligence (AI)

- Fostering a culture of transformation

Interestingly, from the list of topics that digital business is interested in publishing, the only perspective that they have listed to relate to humans/humanity is social impact.

\section{DISCUSSION}

In this article, we demonstrated the need for establishing a journal in digital innovation and human/humanity. The relationship between digital technologies and people has many dubious effects on our humanity. The world is touting the great advantages and benefits that digital innovations have brought to all aspects of the world, yet they fail to explain the impact it has on humans. Moreover, relatively little scientific work has been done to truly assess the benefits and adverse effects on all aspects of human nature. Despite the evident deafening level of rhetoric on the negative effects of technologies, the research community is trailing way behind on this subject, thus allowing overzealous innovators to coercively push improper and inadequate novel technologies onto the world in the name of progress and necessary evolution (not to compare it with the cliché 'necessary evil').

We used three methods to search for journal outlets where digital innovation and transformation research is published: Publish or Perish (Harzing, 2007) desktop literature search application, SCIMAGO and Google search engine. Our quest to identify aggregate and consolidate journals where researchers can publish their digital innovation articles, revealed that:

1. There is no specialized journal or a cluster of similarly specialized journals that are focused on digital innovation and transformation. As a result, all digital innovation and transformation articles are published in a wide array of journals. We identified 33 journals and it is clear from their titles that they do not cluster well in terms of subject matter.

2. Looking at 'Human' and 'Society' in the digital innovation and transformation type of journals, we obtained similar results with only few journals. Note that in this area of research, we found a total of six articles in digital innovation and human and 23 articles in digital transformation and human (some of which were published in conferences).

3. Searching for digital innovation and humanity journals in SCIMAGO returned zero results. To that effect, we improvised and used pre-specified categories closest to our subject matter of interest, namely human-computer interaction, innovation, and management of technology. Both searches showed that the journals in those areas have no focus on humanity and most are not multi-disciplinary.

4. Using SCIMAGO, we researched for journals that have the word 'innovation' in the title and found 62 journals, six of which were identified to be potentially close to digital innovation and transformation, however, the journal titles used utilized the term 'technology' instead of digital.

5. Finally, by manually using google search engine, we identified five journals (listed below). There was one journal of innovation in digital ecosystem that was discontinued in 2016. A second journal was in innovation and technology management, which is not really core to digital innovation, however, we kept it because it is very close and adequate. The third journal is digital innovation in the build environment, which focuses on buildings, and therefore is far from our objective. 
Therefore, we are left with only two journals, namely innovation in the digital economy and digital business, both of which do not have a human/humanity focus. We summarize the five journals below for convenience.

1. Journal of Innovation in Digital Ecosystem discontinued in 2016 and does not have any description on their website)

2. International Journal of Digital Innovation in the Build Environment (IJDIBE)

3. International Journal of Innovation and Technology Management (IJITM)

4. International Journal of Innovation in the Digital Economy (IJIDE)

5. Digital Business

Evidently, researchers do not have appropriate journals to publish their works on digital innovations and transformation. Those who work in this area have to align and manipulate their papers to fit into the existing classical and outdated journal's missions, agendas, and politics. Our research finds that there are few journals that are adequate to publish research works in digital innovation and transformation and only found two journals focused on digital innovation. There is not one journal that aims and targets the human/humanity aspect of digital innovation and transformation.

\section{CONCLUSION}

This paper is the first to appear in the Journal of Digital Innovation for Humanity (JDIH), with an attempt to give strong reasoning of why the journal is necessary. JDIH examines issues at the intersection of the humanities, physical and social sciences, organization and management, environmental sciences, and information technology. It is also interested in the impact of digital innovations and resulting transformation on the full impact chain line of the individual, family, community, society, organization, institution, government, and environment.

The idea of JDIH arose from the chaotic fast-evolving technological reality created by digital innovation zealots, visionaries, and leaders, who in their own paradigm shift, built various social media, internet of things, artificial intelligence, blockchain (cryptocurrencies) and data science, digital applications to materialize the first version of the digital-human. As nature always works to maintain balance, the human-condition is replaced with the digital-condition. With all the promised benefits, these innovations have also been impressive in the way they have disrupted existing and well-established paradigms, notions, and processes. Research about this disruption has been primarily in the business arena; we are yet to discuss how it has disrupted and changed our lifestyle, behavior, psychology and physiology.

Proper dialogue at this digital-to-human frontier is being ignored and efforts to bring all stakeholder together into one single forum must be realized. This is the mission of the proposed Journal of Digital Innovation for Humanity - JDIH. 


\section{REFERENCES}

1. Acs, Z. J., \& Audretsch, D. B. (1988). Innovation in large and small firms: an empirical analysis. The American economic review, 678-690.

2. Acs, Z. J., \& Audretsch, D. B. (1988). Innovation in large and small firms: an empirical analysis. The American economic review, 678-690.

3. Damanpour, F. (1991). Organizational innovation: A meta-analysis of effects of determinants and moderators. Academy of management journal, 34(3), 555-590.

4. Damanpour, F. (1992). Organizational size and innovation. Organization studies, 13(3), 375-402.

5. De Jong, J. P., \& Kemp, R. (2003). Determinants of co-workers' innovative behaviour: An investigation into knowledge intensive services. International Journal of Innovation Management, 7(02), 189-212.

6. De Jong, J. P., \& Kemp, R. (2003). Determinants of co-workers' innovative behaviour: An investigation into knowledge intensive services. International Journal of Innovation Management, 7(02), 189-212.

7. Edison, H., Bin Ali, N., \& Torkar, R. (2013). Towards innovation measurement in the software industry. Journal of Systems and Software, 86(5), 1390-1407.

8. Dibrell, C., Davis, P. S., \& Craig, J. (2008). Fueling innovation through information technology in SMEs. Journal of small business management, 46(2), 203-218.

9. Fichman, R. G., Nambisan, S., \& Halpern, M. (2014). Configurational thinking and value creation from digital innovation: The case of product lifecycle management implementation. In Innovation and IT in an International Context (pp. 115-139). Palgrave Macmillan, London.

10. Fruhling, A. L., \& Siau, K. (2007). Assessing organizational innovation capability and its effect on e-commerce initiatives. Journal of Computer Information Systems, 47(4), 91-103.

11. Galán-Díaz, C., Edwards, P., Nelson, J. D., \& van der Wal, R. (2015). Digital innovation through partnership between nature conservation organisations and academia: A qualitative impact assessment. Ambio, 44(4), 538-549.

12. Geiger, S. W., \& Cashen, L. H. (2002). A multidimensional examination of slack and its impact on innovation. Journal of Managerial issues, 68-84.

13. Hage, J. T. (1999). Organizational innovation and organizational change. Annual review of sociology, 25(1), 597-622.

14. Harzing, A.W. (2007). Publish or Perish, available from https:// harzing.com/resources/publish-or-perish

15. Moore, G., \& Hörl, E. (2014). Rethinking the humanities at the age of digital technologies: Ecological and organological perspectives. Digital Studies Seminar.

16. Nambisan, S., Lyytinen, K., Majchrzak, A., \& Song, M. (2017). Digital Innovation Management: Reinventing innovation management research in a digital world. Mis Quarterly, 41(1).

17. Palmberg, C. (2004). The sources of innovations-looking beyond technological opportunities. Economics of innovation and new technology, 13(2), 183-197.

18. Yamamoto, J., \& Ananou, S. (2015). Humanity in the Digital Age: Cognitive, Social, Emotional, and Ethical Implications. Contemporary Educational Technology, 6(1), 1-18. 
19. Yoo, Y., Lyytinen, K. J., Boland, R. J., \& Berente, N. (2010). The next wave of digital innovation: Opportunities and challenges: A report on the research workshop 'Digital Challenges in Innovation Research'.

\section{AUTHOR'S BIOGRAPHY}

Dr. Raafat George Saadé is a professor at Concordia University. He was awarded the Canadian National Research Council fellowship at McGill University. Dr. Saade has published over 115 research articles many of which in top tier journals such as Fuel, Intl. Journal of Numerical Methods in Heat \& Fluid Flow, Information \& Management, Decision Sciences, Decision Support Systems, Computers in Human Behavior, IEEE, Journal of Organizational Change Management, and Expert Systems with Applications. His work has been cited over 3552 times and has an h-index of 22. He is multidisciplinary and interested in the fusion of theories through divergent thinking, and their operationalization to solve all types of problems. His current research interests are in digital innovation and its impact on humans, digital economy and organizational transformation, change management, and elearning. 